Article

\title{
Archaeological Sites' Management, Interpretation, and Tourism Development-A Success Story and Future Challenges: The Case of Bibracte, France
}

\author{
Abdelkader Ababneh (D) \\ Department of Tourism \& Travel, Yarmouk University, Irbid 21163, Jordan; abdelkader@yu.edu.jo
}

Citation: Ababneh, A

Archaeological Sites' Management, Interpretation, and Tourism

Development-A Success Story and Future Challenges: The Case of Bibracte, France. Heritage 2021, 4 , 2261-2277. https://doi.org/ 10.3390/heritage4030128

Academic Editor: Nick Schiavon

Received: 5 August 2021

Accepted: 1 September 2021

Published: 7 September 2021

Publisher's Note: MDPI stays neutral with regard to jurisdictional claims in published maps and institutional affiliations.

Copyright: (C) 2021 by the author. Licensee MDPI, Basel, Switzerland. This article is an open access article distributed under the terms and conditions of the Creative Commons Attribution (CC BY) license (https:// creativecommons.org/licenses/by/ $4.0 /)$.

\begin{abstract}
Bibracte is described as a well-managed property with significant heritage value. Even as the site's managing body and its partners continue to deliver encouraging and engaging projects, there are barriers to success. Thus, the primary purpose of this study was to identify and analyze the possible future challenges that the current management may encounter. This study used a field work methodology, and comprised interviews, observations, guided visits, discussions, discourse analysis, and the review of an important corpus of material, from which conclusions were drawn. Significant problems arising from various causes were identified. The results reveal that despite the appropriate heritage management, interpretation, and tourism development practices, the heritage and tourism potential remain not fully captured. The management of the site has established its notoriety as an important research center for experimental and educational archaeology, rather than as an important tourist attraction. Thus, the site has failed to become a popular tourist destination. These difficulties are said to have been molded and enforced by imperatives connected to the site and its surroundings, as well as the Réseau des Grands Sites de France title. This research may contribute to elucidating heritage sites and their unknown management difficulties, which will be beneficial to the sites' employees and visitors.
\end{abstract}

Keywords: site planning; heritage interpretation; heritage tourism; on-site experience; challenges; Bibracte; France

\section{Introduction}

In France, the importance of natural and cultural heritage has long been recognized by national heritage authorities [1,2], and the need for their management and development is well emphasized [3]. Historical landscapes, archeological sites, and natural parks are regarded, for example, as properties of scenic, political, social, and economic importance, and are related, in different cases, to national identity, collective memory, and tourism progress [4]. These unique places are extremely important, and must be appropriately managed. Thus, different national guidelines and policies have been framed, and different management systems and practices have been introduced [5]. For example, the Ministry of Ecological Transition and Solidarity, the Forest Office, the Center of National Monuments, the Union of National Museums, the Littoral Conservatory [6] and the Réseau des Grands Sites de France (The Network of Grand Sites of France), the Regional Directorates of Cultural Affairs, and the Regional Directorates of Tourism are among the most important institutions responsible for heritage management. However, each of these institutions is related to a specific legislative framework, notably including the law of 1913 creating the index of registered historical monuments (monuments historiques classés), and the law of 1930 creating the index of registered scenic places and landscapes (sites classés). Moreover, the overall valorization of natural, architectural, cultural, urban, and archaeological sites is underpinned by the Code du Patrimoine (Code of Patrimony), which is activated by the Ministry of Culture, and the Code de l'Environnement (Code of the Environment), which is activated by the Ministry of the Environment. In other words, heritage policies 
are evolving, and it is no wonder that management schemes for archaeological sites are well established.

However, the different heritage management practices were not challenge-free in their implementation. It has been noted that despite the obvious branding of heritage sites on local, national, and international levels, many current issues and future challenges exist $[2,7]$, and these challenges may impact management, interpretation, and tourism development at archeological sites.

This study argues that while different sites and their development are widely recognized for their quality management, they have not been without their difficulties. The purpose of this study was to evaluate the potential and progress in heritage management practices at archaeological sites, and to identify some of the challenges that are faced and require attention when undertaking interpretation and tourism development. Hence, the aim of this practical study was to provide a critical analysis of the management and challenges faced by archaeological sites located in rural areas, focusing on the archaeological site of Bibracte, France. Bibracte is located in a very problematic context, facing both forest land expansion and rural environmental degradation. The changing landscape of wooded lands will have direct and indirect impacts on the nature and character of the archaeological setting [2,7].

This study will show how the site of Bibracte succeeded in positioning itself as a model of heritage management in both national and international terms. The site was identified as an exemplar that demonstrated heritage management qualities and practices viewed as a model by other sites in the same region, such as MuséoParc in Alésia. Additionally, this study will show how the different issues related to the various aspects of the management process of the site were overlooked due to the complexity of the heritage management process itself. Potentially, even if the site has been substantially managed internally, with a high-quality interpretation, some challenges could still be encountered [8,9].

Understanding the management process and the context of interpretation and heritage tourism, how these successful management approaches were reached, how they developed overtime, and what challenges were facing the overall valorization process of the archaeological setting are crucial elements to take into account when considering how a heritage resource should be managed, interpreted, and developed in touristic terms. An important aspect of heritage management is the need to evaluate contemporary management and the identification of potential challenges to ascertain whether specific measures could be put in place in order to achieve better heritage management practices $[10,11]$. This study attempts to provide the relevant institutions with an overview of the current situation, as well as the challenges that they need to address in order to realize sustainable site management.

\section{Literature Review}

As a wide-ranging concept, the definition of heritage management is endorsed in different scholarly works $[12,13]$. The term heritage management refers to "the systematic care taken to maintain the cultural values of heritage assets for the enjoyment of present and future generations" [14]. Furthermore, the concept of heritage management, according to [15], is the protection of the dual legacy of natural and cultural heritage and the identity of local communities. Ultimately, heritage management is a collective process that encompasses site identification, stakeholders' involvement, conservation assessment, significance statement, current management appraisal, and strategy definition [16-19]. A review of the literature suggests that heritage management could be approached to valorize different heritage resources, such as archaeological sites, natural parks, heritage properties, and artifacts [20,21]. Furthermore, the value of intangible archaeological heritage is becoming more widely recognized as a significant component, since it enriches the tourist experience [22].

Scholarly work has demonstrated that heritage management is increasingly conceived at archaeological sites in order to increase public awareness, generate tourism and revenue [23], and address current and future problems [24]. Heritage management is regarded as a tool to enhance sites [25], stimulate the visitor experience, and contribute to the welfare 
of the local context [26]. More specifically, heritage management stimulates an appropriate canvas upon which understanding of the needs and responses of heritage proponents and users are closely allied. However, successful heritage management practices are essential to meeting these ends. Limits of acceptable change, visitor impact management, visitor experience, resource protection, and carrying capacity [27], as well as visitor flow management process, visitor management, and the recreation opportunity spectrum [28], are some of the possible management frameworks proposed to minimize the negative impacts of tourism on archaeological and natural sites.

Many studies have tried to define models for heritage management planning, such as various international guidelines (World Heritage Convention 1972, Burra Charter 1999, ICOMOS Charter 1990), in addition to some heritage management models [29,30] to provide heritage sites with planning sequences. The authors of [31-37] propose effective management models centered on three axes-namely, identification of the heritage site and its associated significance, choice of the management strategy and policy and, finally, revision and monitoring. It can perhaps be argued that heritage management is generally approached in two ways: the conventional/traditional and the value-based approaches [38-40]. While the first approach has been described as top-down, reactive, occasional, and partial, the second is proactive, integrated, and continuous [41]. The value-based approach encourages cooperation between the concerned stakeholders and the analysis of their interests [42]. In addition, this approach addresses the symbiotic interplay between heritage management and tourism development. Site management approaches have shifted to more robust approaches that may be considered to be forms of living heritage management [43] and historic landscape management in reaction to the numerous limitations and shortcomings in heritage management practices [44].

Heritage management underpins both heritage tourism and heritage interpretation. Management of archaeological sites involves more than protection and preservation measures. The authors of [45], in their training manual, point out that heritage management is concerned with issues of visitor and facility management, as well as presentation and interpretation. Interpretation is widely applied at archaeological sites to impart information, reduce negative impacts, manage visitors, and raise awareness [46,47]. A review of heritage interpretation literature $[48,49]$ identified the impact that interpretation may have on the quality of heritage management, the quality of services, and the visitor experience [50-52]. The author of [53], in studying the impacts of interpretation on visitors' knowledge, attitudes, and behavioral intentions, noted that interpretive programs were a major factor in generating a positive perception regarding appreciation and awareness of the value of heritage resources. Different researchers [51] have suggested different tips and best interpretation practices. In general, content should be pertinent to the site, while the personal or non-personal interpretive methods [54] should be adapted to the ranging public.

Literature on both heritage and tourism management demonstrates the diverse and interrelated links between the two aspects $[55,56]$. Despite the paradoxical relationship between tourism and heritage management $[57,58]$, heritage tourism management is considered to be a source of funding, preservation, cooperation, and the generation of products and quality experiences. Indeed, heritage and tourism could be considered to be vehicle to promote inter-sector cooperation and intercultural dialogue and development. Studies on heritage management and tourism predominantly focus on the balance between the aims and the values of tourism and heritage management [56]. However, sustainability discourse has become straightforward in the philosophies of heritage and tourism management [59]. As such, heritage site managers play a key role in the process of heritage management. For example, the task of site managers is to deal with daily operational issues that occur at archaeological sites, including crowds, vandalism, security and safety, and welcoming visitors [60]. According to [45], site managers' role comes in a number of forms, including developing a holistic view of cultural tourism management, communicating and coordinating with other actors, and using tools that facilitate integration. 
As mentioned by different scholars [61,62], archaeological sites are prone to management challenges. Practically, site management challenges include socioeconomic and political problems [63], limited funding, actors' dominance and power concerns [60], institutional conflicts [61], limited expertise [64], and environmental and community pressures [65].In addition, issues related to authenticity, integrity, and sustainability [66] have also been identified as core challenges for site management [67]. The literature has referred to different countries around the world with heritage management challenges, including, for example, the United Kingdom, the United States of America, China, Jordan, Zimbabwe, the United Arab Emirates, Colombia, and Australia [30].

Existing literature has not yet completely investigated heritage management techniques at Bibracte, although a number of studies have substantiated the symbiotic link between the site of Bibracte and its cultural landscape settings. The authors of [7], in assessing perceptions of cultural landscapes in Bagendon and Salmonsbury (United Kingdom), Ulaca (Spain), and Bibracte (France), claimed that landscape management practices are not a major part of stakeholders' perceptions. A more recent study [2], in an analysis concerned with the place of archaeology in integrated cultural landscape management, turned to examples of four Iron Age oppida sites from Europe (Spain, England, and France) in order to review the present integration of archaeology into landscape management. The case studies show that there is a weak awareness by stakeholders with regard to practices of landscape management; thus, the integration of archaeological sites into their wider context is problematic. Despite that, many international charters, guidelines, studies, and other research efforts have conceived an exemplary and visionary approach to heritage management; however, archaeological site management still requires further understanding and research, particularly concerning its management challenges. Based on the previous arguments, the heritage management process must be based on an understanding of the future dynamics of the social, political, and cultural structures of the country and the wide-ranging public [68]. In this regard, the authors of $[60,69]$ suggest that in order to solve emerging problems and issues of heritage management, site managers should anticipate and look to the future. In conclusion, despite the growing interest in scientific and practical research in the field of heritage and tourism in France [70], this study contends that little has been undertaken to define the challenges facing heritage management in France [3].

\section{Materials and Methods}

The problem that this paper seeks to address is that there are always challenges to consider, even if the site is successfully positioned in terms of appropriate heritage management practices (as long as the site is listed as one of the Grands Sites de France, a reliable indicator of best management practices).The scope of this study is the investigation of the heritage management process at the archaeological site of Bibracte, France, with twofold objectives: to understand the heritage management process at the site, and to explore and discuss the main challenges associated with the management of archaeological sites in the context of a changing rural landscape. This study endeavors to analyze the current heritage management clearly, and thereby understand and explore the challenges facing heritage site management. Consequently, this study provides a critical analysis of the different individuals and institutions involved in the management of the site. Bibracte was chosen as a case study based on the meaningful heritage management approaches applied to this dynamic site.

This study is descriptive, analytical, critical, interpretive, and explorative. Data were collected through fieldwork research; the author had the opportunity of a research stay of almost three weeks during January and February 2019 at Bibracte, as well as the European archaeological research center based nearby and managed by the same public body as the site. During this field study, the author adopted a combination of research methods, including guided visits to the museum (interpretation center), predetermined face-toface interviews, meetings, and open discussion with key professionals at the site (the director of the site, the curator, and those responsible for interpretation programs, tourism 
development, site management, operation management, and the editorial service). The number of interviews ( 8 people), and their selection (4 female, 4 male) was based on their expertise (average of 10 years of expertise). The focus of those interviews was to explore the current management situation and the potential future challenges. These visits, interviews, and discussions were sources of valuable information about the institutional management structure and the applied actions and projects. Participants expressed their views and also their concerns about the current management, interpretation, and tourism development. The interviews and discussions took place at different times of the day and in different places, such as the museum, the interpretation center, the archaeological site, the parking lot, the souvenir shop, the working offices, the cafeteria, and the research center. In order to portray the real situation, observations were also recorded at the archaeological site and the museum, with a predefined list of factors to be observed (interpretive techniques, themes, and content). All of the interpretive materials at the museum (interpretation center) and the site were experienced and studied. Interpretive materials were photographed and their content was noted. The observations highlighted additional information with regard to the interpretation context. To further broaden the understanding of the site and its management, the author referred to important literature and documents (books, magazines, projects, grey literature, plans, maps, reports, and brochures) available at the site and at the library of the research center, such as: Valorizing Invisible Archaeological Sites (2004), Guiding Schema Management and Tourism Development of Mont Beuvray (1997), the Annual Activities Report (2017), and the Labeling Candidature File (2013).

The collected data were the object of discourse and critical analysis and interpretive policy [71]; all of the gathered data were collected in the French language - translated by the author into the English language-and transcribed on paper sheets prepared for this purpose. The data were reviewed several times, compared to one another, and abstracted and categorized thematically. The categories were then carefully reviewed, analyzed, critiqued, and interpreted to conceptualize and identify challenges according to the investigated issues of this study. The reliability of this study was ensured by using different methods of data collection. In addition, an earlier version was commented on and reviewed by the director of the site.

\section{Bibracte: The Case Study}

Bibracte is located in east-central France, surmounting the highlands of the Parc Naturel Regional du Morvan in the heart of Burgundy [72-75], and lies between the departments of Nièvre (58) and Saône-et-Loire (71) (Figure 1). The site is located within a rural area that has experienced a tremendous reduction in its population since the end of the 19th century $(80 \%)$, with figures presently as low as 10 inhabitants per $\mathrm{km}$ around the site. This reduction in the population has, in turn, strongly affected the landscape, with a large part of the agricultural land being turned into forest, which now covers half of the territory. Since the late 1970s, Bibracte has been turned into a public estate of nearly 1000 ha [76]. The site is that of a short-lived town from the 1st century BC, surrounded by $5.2 \mathrm{~km}$ long ramparts and extending over 135 ha (and initially even more: $200 \mathrm{ha}$ ). It is a key historical site, having been the site of several major events in Caesar's Gallic Wars, as well as being a key archaeological site, with its extensive excavation as early as the 1860 s having been formative in the field of French Iron Age archaeology [77]. Bibracte's roots are steeped in the history of France, dating back to the end of the Iron Age, and the site has seen various changes throughout its history. Bibracte, which was the capital of the Gallic Aedui people for a century, is arguably one of the richest Gaulish cultural sites in Europe thanks to its cultural landscape, architecture, and historic and material development [78]. 


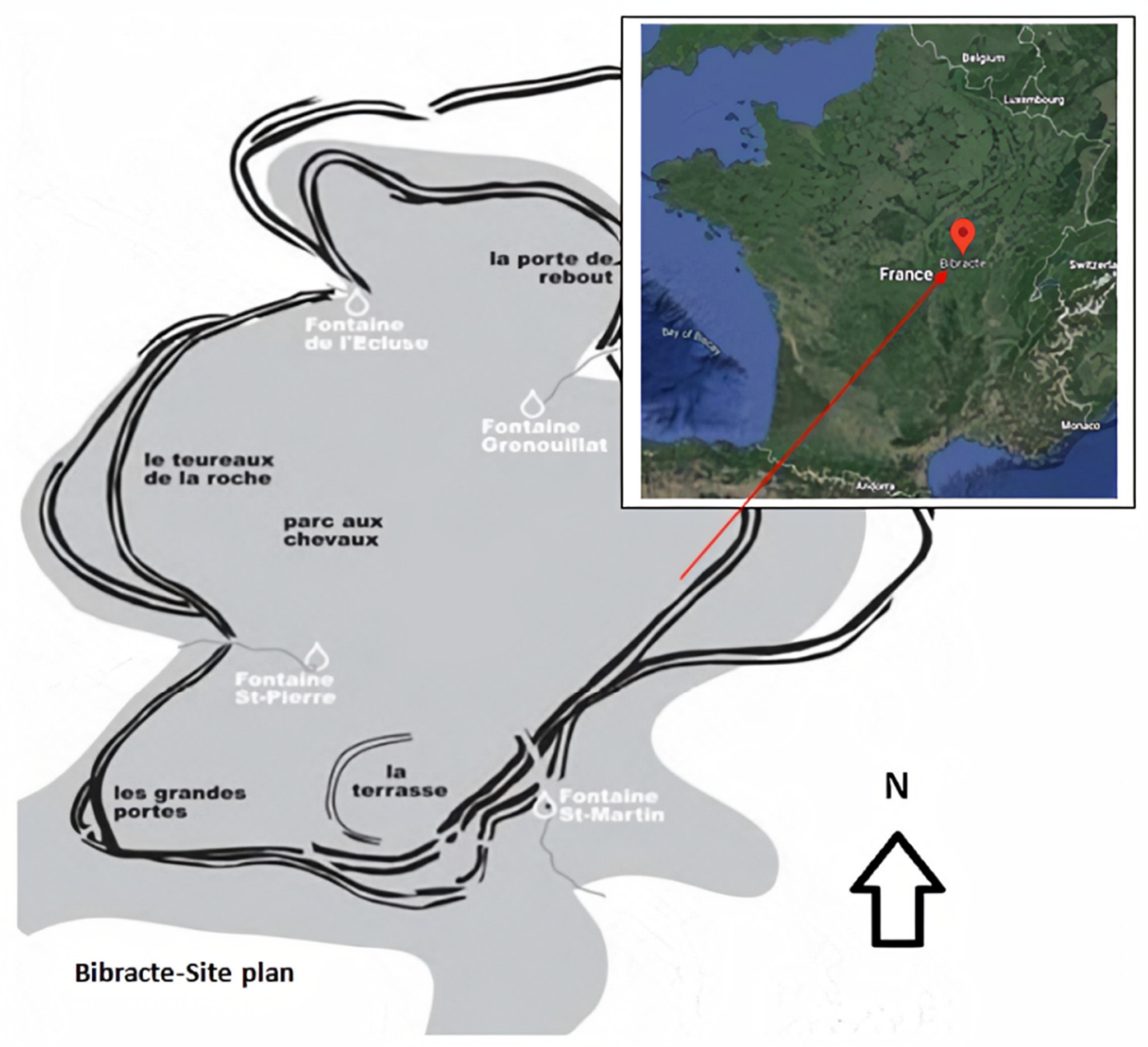

Figure 1. Location of the site.

The site has been the subject of archaeological research since the 19th century, when the fortified Gaulish town was first excavated by Jacques-Gabriel and Joseph Déchelette between 1864 and 1907. Their work permitted the identification of the site once mentioned by Caesar as an oppidum. Excavation work stopped a short time before World War I, and resumed in 1984. The second phase of archaeological work was enhanced by the public initiative of the Grands Travaux Culturels. The different archaeological campaigns have revealed important archaeological remains, where most of the visible structures with ramparts and districts date back to the 2nd century (Figure 2). Archaeological evidence of the site had been identified in the first phase (1865-1914), but major excavations in the late 20th century (1984-present) led to the discovery of many more remains. Today, the discovered material is the object of documentation, analysis, interpretation, exposition, and publication. There remains great potential of uncovering further archaeological evidence. Nevertheless, the site will continue archaeological work and research studies for as long as it is not completely excavated and, thus, various questions remain unanswered. The site, which is currently known as Mont Beuvray, offers material evidence of local occupation and historic development. The site also provides a practical example of the interaction between cultural and natural heritage.

Bibracte has different distinguished resources of cultural heritage and tourist attractions that have helped the site to establish its notoriety. In fact, the site has established itself as an important research center for experimental and educational archaeology. It has become a reference in this field, as it involves different archaeological missions and research visits from different European countries. Generally, the broader adjacent area of Bibracte has a population of 37,500 and an area of $5134 \mathrm{~km}^{2}$. The surrounding area is exceptionally rich in woodlands, forests, and vegetation corridors. On the one hand, these natural rural landscapes are considered to be another influential element in the development of the overall cultural landscape of the archaeological area; on the other hand, they 
are very valuable resources in terms of cultural and natural heritage. Bibracte is home to an archaeological site and museum/interpretation center, an archaeological research center, a natural regional park, and an exceptional rural setting. Meanwhile, the site was designated as one of the Grands Sites de France in 2007, a National Historic Monument in 1984, a special natural conservation zone in 2000, and a fragile landscape buffer zone. In fact, as the status of the site and its management programs has grown, different aspects of heritage management at the site have been improved [74]. These features, together, have increased the popularity of this site. Consequently, the complimentary union of these resources is believed to be sufficient to meet the needs of various publics and tourism typologies. The site has not only developed its reputation for archaeology and research, but has also started to attract tourists' attention.

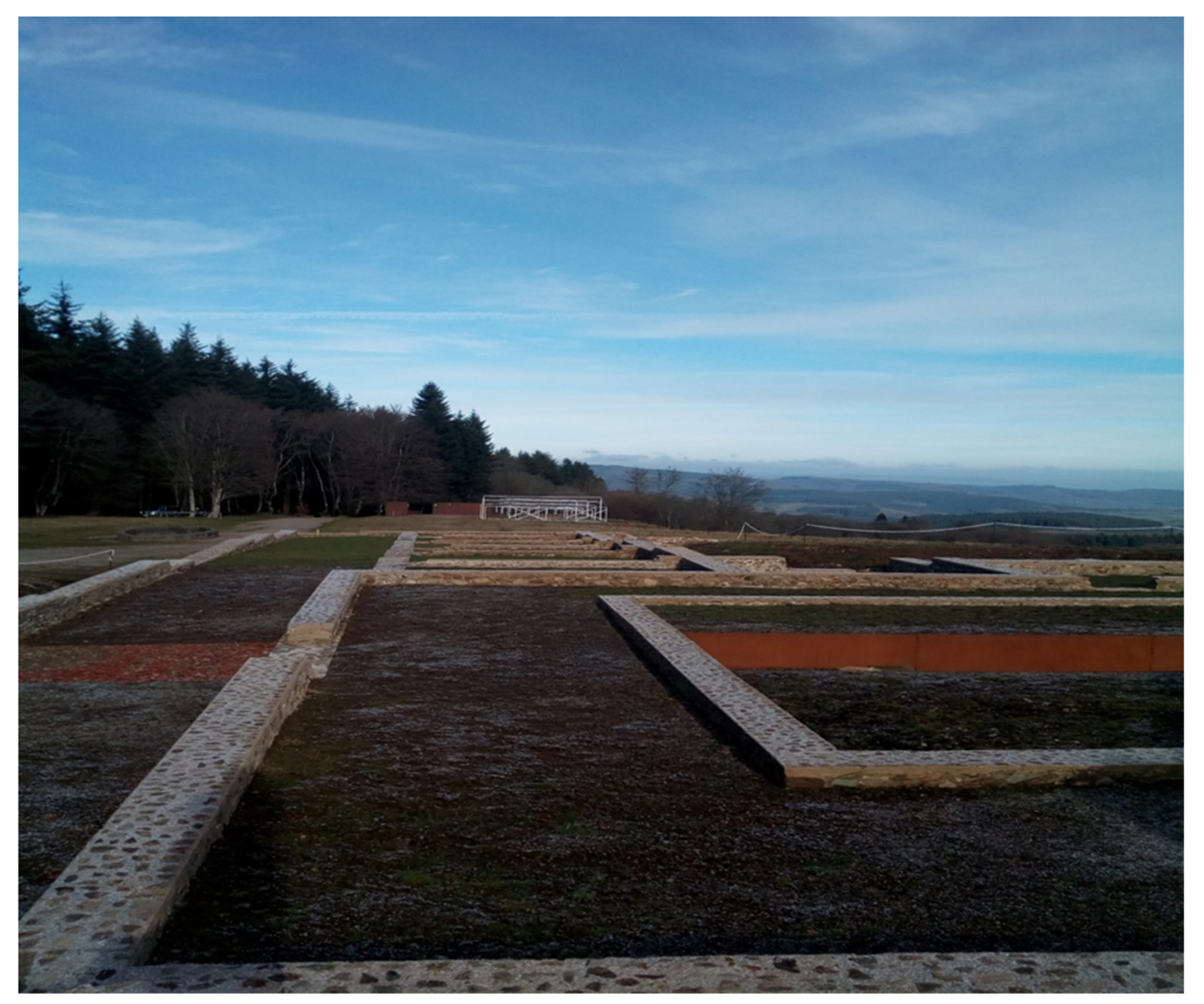

Figure 2. View from the site.

\section{Analytical Context}

Current Situation: Management, Interpretation, and Tourism

Since 1980, the site's ensemble (archaeological site, museum/interpretation center, and research center) has been the subject of several management initiatives and activities. Heritage management in Bibracte began in 1984, with the introduction of the Ministry of Culture's worldwide research program, which was driven by the president of the republic at the time. The complex is presently managed by the government, having been established in 1991 and awarded the status of public establishment for cultural cooperation in 2008. Bibracte now has total management power, and the site's numerous management responsibilities are split among its three subsections: resources, culture, and science (Table 1). The statutory obligation, according to Bibracte's director, "is to enhance research and communication and to further sustainable development in light of the "Plan de gestion paysagère-landscape management plan" that was updated in 2013 and the "Plan de gestion forestière-forestry management plan" that was validated in 2013"(Guichard, pc. 2019). Bibracte, the site's management organization, is made up of members of the French government, the Burgundy regional council, the Nièvre and 
Saône-et-Loire departmental councils, the Morvan natural regional park, the Center of National Monuments, and the National Center for Scientific Research. The site's exemplary management planning, according to the fieldwork, can be attributed to financial sufficiency and human capital; "in fact, the site's current annual budget is 4 million and 600 thousand euros, and the site also provides job opportunities for about 35 technical, scientific, and operational employers"(Boutillie, pc. 2019).

Table 1. Key management indicators.

\begin{tabular}{|c|c|}
\hline Item & Description and Details \\
\hline Governance & $\begin{array}{l}\text { It is an autonomous public-run site managed byBibracte EPCC (Etablissement } \\
\text { public de cooperation cultural) }\end{array}$ \\
\hline Legislative framework & $\begin{array}{c}\text { The law of } 1913 \text { creating the index of registered historical monuments (monuments } \\
\text { historiques classés). } \\
\text { The law of } 1930 \text { creating the index of registered scenic places and landscapes (sites } \\
\text { classés).The Code du Patrimoine (Code of Patrimony)and the Code de } \\
\text { l'Environnement (Code of the Environment), }\end{array}$ \\
\hline Financial resources & Financial autonomy, with a total annual budget of more than EUR 4 million \\
\hline Human expertise & $\begin{array}{l}\text { Human resources work in three departments, including the resource section, the } \\
\text { cultural section, and the scientific section. }\end{array}$ \\
\hline Planning system/management policy & $\begin{array}{l}\text { Adopting the policy of the Grands Sites de France, which relies on local authorities } \\
\text { and integrated management methods. }\end{array}$ \\
\hline Branding and labels & $\begin{array}{l}\text { The site was declared as one of the Grands Sites de France in 2007, a National } \\
\text { HistoricMonument in 1984, a special natural conservation zone 2000, and a fragile } \\
\text { landscape buffer zone. }\end{array}$ \\
\hline
\end{tabular}

The museum and the interpretive center, which are regarded as the site's "portal", reflect the philosophy and paradigms on which the site's administration was developed and inspired. The importance of interpreting the site's archaeological material has been acknowledged in several technical studies as being critical to the site's policy. In 1995, the architect Pierre-Louis Faloci was commissioned to build an ultramodern museum to accomplish these goals. Today, the site's two-gallery museum is a significant attraction, and the site is interpreted and presented in a variety of ways to offer more context for the site's narrative and its surrounding environment (Table 2).

It is recognized that the interpretive package with the museum's spatial plan benefits from vibrant, dynamic, enthusiastic interpretive methods and a high-quality design, all of which contribute to a quality experience. The carefully drafted interpretive means were prepared by the site staff, based on research knowledge and studies produced after the excavation works, and on publications made available by the research body at the research center. The site-in particular, the museum-hosts a diverse range of interpretative media (Figure 3). These media are available in a variety of formats, including on-site and off-site, personal and non-personal, static and interactive tools. Furthermore, these approaches were developed and anchored in locations and contexts that made the site physically and culturally accessible to all visitors. The multilingual narratives trace the history of the people of Bibracte and the development of their cultural history on a general level, allowing for the identification of the site's tangible cultural heritage and creating specific interactions between visitors and the site's surroundings. 
Table 2. Keydetails of the interpretive center.

\begin{tabular}{|c|c|c|c|}
\hline Gallery & Themes & Subthemes & Interpretive Tools \\
\hline The upper gallery & $\begin{array}{l}\text { Iron Age urbanism phenomena of } \\
\text { Bibracte and Europe }\end{array}$ & $\begin{array}{l}\text { - A well-ordered rural landscape } \\
\text { - A shift in scale } \\
\text { - A century-long lifespan } \\
\text { - Spanning the content } \\
\text { - A complex society } \\
\text { - From myth to history }\end{array}$ & $\begin{array}{l}\text { Brochures, dioramas, maps, } \\
\text { models, labels, signs, posters, } \\
\text { videos, films, narrations, } \\
\text { testimonies, audiovisual shows, } \\
\text { data shows, touchscreens, } \\
\text { modeled excavations, modeled } \\
\text { houses, archaeological material, } \\
\text { tour guides, guided tours, } \\
\text { self-guided tours, audio guides, } \\
\text { web site, social media graphic } \\
\text { models, digital mock-up, books, } \\
\text { research articles, magazines, } \\
\text { newsletters, training and } \\
\text { educational events }\end{array}$ \\
\hline The lower gallery & $\begin{array}{l}\text { Archaeological evidence and } \\
\text { historical development }\end{array}$ & $\begin{array}{l}\text { - In the footsteps of Caesar } \\
\text { - An urban building plan } \\
\text { - A town in the ascendant } \\
\text { - Consumption and production } \\
\text { - The inhabitants of the oppidum } \\
\text { - The transfer of the capital }\end{array}$ & $\begin{array}{l}\text { Brochures, dioramas, maps, } \\
\text { models, labels, signs, posters, } \\
\text { videos, films, narrations, } \\
\text { testimonies, audiovisual shows, } \\
\text { data shows, touchscreens, } \\
\text { modeled excavations, modeled } \\
\text { houses, archaeological material, } \\
\text { tour guides, guided tours, } \\
\text { self-guided tours, audio guides, } \\
\text { web site, social media, books, } \\
\text { graphic models, digital mock-up, } \\
\text { research articles, magazines, } \\
\text { newsletters, training and } \\
\text { educational events }\end{array}$ \\
\hline
\end{tabular}

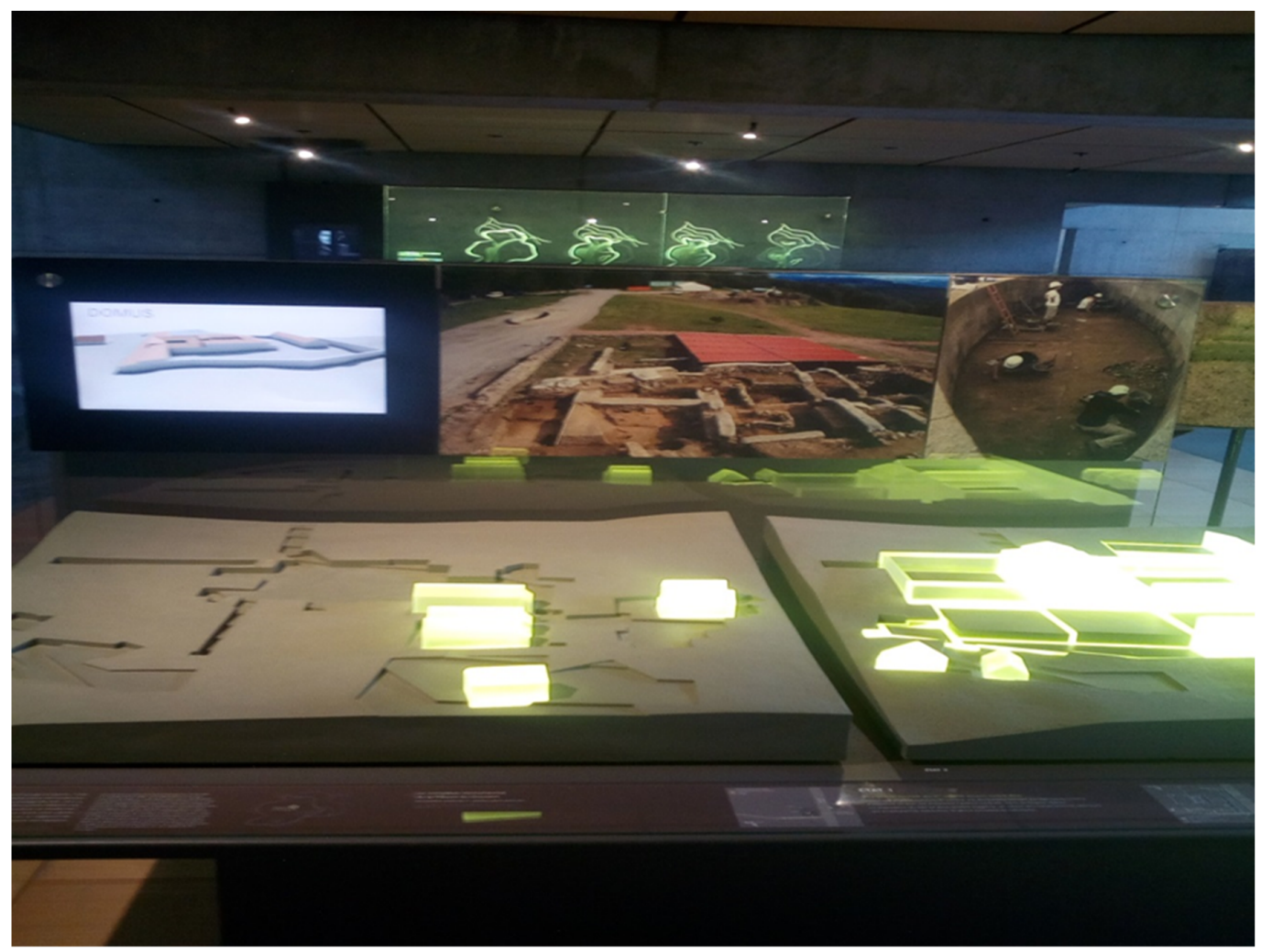

Figure 3. Combined interpretive techniques including panels, tactile screens, 3D reconstruction, dioramas, and maquette. 
From a tourism standpoint (Table 3), Bibracte is home to significant cultural and natural resources, with a variety of tourism possibilities in and around the site, as well as an exceptional rural life in the surrounding area. The rural environment of Bibracte and the surrounding woodlands encapsulates the ancient relationship between nature and people. These resources are frequently linked to many types of tourism, including nature, adventure, sports, rural, and historic tourism. The archaeological site, the museum/interpretation center, the research center, and the environment are all important aspects of current tourism in the region. As evidenced by the meetings, "in the last decade, the site had stable visitation of around 80,000 visitors to the archaeological site and 45,000 visitors to the museum" (Ayashi, pc. 2019). Locals from Burgundy make up a large percentage of the tourists (35\%), while foreigners make up around $25 \%$ of the visitors, with the majority coming from the Netherlands and Belgium. Families, students, and heritage and nature enthusiasts continue to be the most common types of visitors, and they are mostly drawn to nature-based activities such as sightseeing, walking, and visiting cultural attractions. Tourists primarily visit the archaeological site and its associated centers, and they rarely visit other attractions. To meet visitor demand, Bibracte has enlarged its tourist amenities to include a restaurant, two dormitories, a souvenir store, a café, and an information center at the museum's entrance. Bibracte has also put in place a number of promotional and communications programs, along with activities aimed at promoting history and increasing its tourist appeal.

Table 3. Key tourism indicators.

\begin{tabular}{|c|c|}
\hline Item & Description Details \\
\hline Tourism resources & $\begin{array}{l}\text { Archaeological monuments, museum, historic landscape, } \\
\text { handicrafts, souvenir products, historic events, traditional events, } \\
\text { traditional cuisine, traditions and customs, rural landscape, } \\
\text { rivers, agricultural lands and products }\end{array}$ \\
\hline Tourism potential & Heritage tourism, rural tourism, ecotourism, adventure tourism \\
\hline Services and amenities & $\begin{array}{l}\text { Accommodation, restaurants, museum, research center, visitor } \\
\text { center, souvenir shop, library }\end{array}$ \\
\hline Visitors to the site & Locals and Europeans, families, students, young couples \\
\hline Visits and activities & $\begin{array}{l}\text { Sightseeing, walking, touring, cultural visits, guided and } \\
\text { non-guided visits, school visits, excavation training programs }\end{array}$ \\
\hline Accesibility & $\begin{array}{c}\text { Bibracte is a long way from any major urban centers or cities, and } \\
\text { cannot be reached by motorway or train }\end{array}$ \\
\hline
\end{tabular}

\section{Findings and Discussion}

The following section is based on the data gathered during the fieldwork research, as well as the author's analysis and interpretation. The primary problems at the archeological site of Bibracte connected to the three examined themes (heritage management, heritage interpretation, and tourism) will be emphasized, evaluated, and debated. In addition, some proposals for heritage management will be offered. The main argument for this research study was that the site of Bibracte has significant heritage management significance, based on its long history of heritage management. The site has succeeded in becoming one of the first managed heritage sites in France, and is one of the most recognizable sites in Europe, but there are various specific challenges to confront with regard to heritage management. To address such issues, a significant transition-from the traditional management strategy of focusing on the site's physical form as an open outdoor museum, to living heritage management [43] and historic landscape management [44] approaches-is necessary.

The case study of Bibracte shows that the managing body has demonstrated practical efficacy in terms of identifying, organizing, managing, and interpreting its heritage resources. The major key components of the site's management include the inclusion of integrated management paradigms such as participatory decision making, training and education, research, site understanding, community engagement, flexible hierarchy, and 
adequate multi departmental management structure. "This kind of integrated management of a piece of national heritage is by far not common in the country. Its development was thanks to unique circumstances: the interest of a former president of the Republic in the place. Nevertheless, the concept of integrated management is making its way in the country, especially through the Grands Sites de France policy of the Ministry of Environment "(Guichard, pc. 2019). According to data collected from the interviewees, different factors that are significant to the successful management of the site were identified, including management, leadership, and financial and decision making autonomy. One of the interviewees pointed out that "the site is believed to be a truly research center of international significance set in a beautiful landscape. The site has a management system with an experienced director and a network of stakeholders". Much of the site's heritage management is provided through Bibracte EPCC (etablissement public de cooperation culturelle), an administratively and financially independent public body. This autonomy has introduced a deeper understanding of the planning system, with more focus on the involvement of the different heritage actors and, ultimately, the conscious decision making in the planning stage of any management, interpretation, or tourism project. Moreover, the need to manage the site and develop the area for future generations was identified as a form of social and cultural capital. The listing of Bibracte on the list of the Réseau des Grands Sites de France was an indicator of the appreciation of the management approach.

However, as various portions of the archaeological site are undiscovered and buried under forest lands, distinct archaeological remnants remain unexcavated. Management of the archaeological site has unique challenges. In this regard, the directors have used a variety of visitor management strategies to protect the site, including building fences, shelters, and viewing platforms; zoning; and using directional information, visitor codes of conduct, and educational interpretative information to spread tourists and tourism activities across the destination. Furthermore, complex archaeological sites with unfinished excavations are not always easily understood; it is generally agreed that site management is based on an understanding of the site's full values. This means that a failure to capture and portray the various site-associated values will lead to a variety of issues in heritage management, particularly in heritage interpretation. Likewise, the need for a system via which to continuously identify the values and the significance of the site according to excavation and research progress has been identified as a challenge. The management faces significant obstacle in the form of forests and the rural context in which the site is located. The woodlands are rapidly growing, making comprehensive identification of archaeological remains and evidence difficult and, therefore, severely influencing archaeological field operations. However, the record of the identified archaeological remains is compiled at the research center and considered as the basis of the published material and the interpretive methods.

The site was inscribed in the Réseau des Grands Sites de France's list for meeting the network's criteria and standards, indicating that the management has represented the network's ideals via its current management strategy. The network has then established best guidelines and practices for protecting and managing heritage sites within their areas. For example, the goal of heritage management is widely understood by the network as "the balance between local inhabitants and stakeholders, visitors, and the spirit of the place (genius loci)" [3]. These best practices have been implemented into the site's management process in order to offer valuable communication through interpretation, engage natural and cultural assets in mainstream planning, cooperate with government and the community, and build professional capacity. Archaeological sites that have been listed on the Réseau des Grands Sites de France's list must adhere to the network's stringent management requirements. This addition, on the other hand, might be viewed as a new difficulty in terms of the site's ability to maintain the same methods and ensure the valuation of the site's resources and its related surroundings.

According to the meetings and observations, the ongoing transformation of the rural environment, with its deteriorating demographic and productive resources, is not promis- 
ing. The area is remote, underserved, and thinly inhabited, with just a few tiny settlements and farmland nearby. Projects in agriculture and forestry are experiencing financial difficulties. This development only confirms the reality that rural regions' demographic concerns have been overlooked, and that heritage management strategies have failed to incorporate solutions that are tailored to the complexity of the rural environment. As a result, this deterioration has the potential to jeopardize the existence of a significant percentage of the area's historic assets, as well as the community's resources. Failure to conserve and develop these assets may result in challenges to the region's growth, as well as the progressive deterioration of the assets' physical and intangible values. Redevelopment of these habitats for rural tourism activities and the establishment of interpretive plans to explain traditional rural life are two possible solutions to this challenge. Tourism is viewed as a solution to promote social and economic progress in rural regions with limited economic prospects. The improvement of rural regions' quality of life is inextricably linked to the enhancement of their local culture and scenery.

In terms of site interpretation, the site museum is an interpretation and visitor facility meant to serve as a platform for valuable scientific research conducted at the archaeological site and research institution. The interpretation indicates a shift in how the Bibracte EPCC views the region's legacy. According to observations, the interpretation approach developed appears to have a degree of variety and creativity. This is well demonstrated by the museum's various and well-crafted interpretive methods, which include the use of original and non-original objects, first-hand experience, and illustrative methods, guided tours, formal presentations, and organized entertainment activities, in addition to physical media such as panels, brochures, and electronic equipment.

The guided tours and observations at the museum suggest that current interpretation appeals to a variety of senses. Furthermore, interpretive methods donot rely on just one sense - they use a variety of means, including visual (films, images), verbal (panels, formal presentations), and tactile approaches (touching) (original and non-original objects, firsthand experiences), live interpretation (guided tours, talks, workshops), and interactive and physical media such as web-based interpretation, electronic equipment, and publications. In addition, other interpretative activities include cooking using an old Roman recipe in the neighboring restaurant, and participating in hands-on seminars for schools and other educational groups.

"A significant deal of the interpretative material was performed by archaeologists and interpretations were frequently taken after the excavation activities had been completed", according to the various notes and perspectives of the research participants-particularly those associated with the museum's work. However, acquiring meaningful interpretation and information will be restricted if archaeological sites are interpreted before their full excavation and comprehension of their archaeological record.

Study respondents reported that "one of the challenges of the current interpretation is changing the stereotype image of visitors to the site". The image of most local visitors was largely believed to consist of primitive communities living in small, undeveloped huts in the forest lands, although the city of Bibracte was one of the most prosperous urban centers. One of the most prominent causes of this, according to respondents, is the underdevelopment of instructional materials in schools and poor public awareness. Another issue is that legacy interpretation is in the hands of archaeologists, and interpretative texts are based on their archaeological studies. Thus, the majority of the interpretation is centered on the site itself and the actual archaeological material connected with it. As a result, the existing interpretation fails to take into account the natural environment as well as the characteristics of rural communities. The museum's interpretative context has been revised and analyzed, and it now seems that the location is culturally, geographically, and environmentally isolated, and detached from its surrounding community. This suggests that interpretive management is overlooking possibilities to increase visitor attention and generate income through tourism. To address this, efforts might include ensuring that all site-based themes are reflected in all areas of public experiences and places. 
Based on field research, it appears that the site has its own archaeology and interpretive initiatives, but that they are not fully integrated with the local culture and natural surroundings. Local culture and natural landscapes are underappreciated and undervalued in comparison to what they should be. As a result, the interpretive themes connected to local nature and cultures have not been given the same level of attention as the interpretative themes relating to the archaeology and history of the site. As a result, site management would benefit from exploring the site's heritage and tourist potential, which may lead to a more complete understanding of site's representations and experience demands for various interpretation and management practices.

From the standpoint of tourist development, it appears that Bibracte and its environs have a diverse cultural and natural heritage, as well as significant tourism potential. "Bibracte, in the hope of enhancing its attractiveness, has taken several steps to enhance its tourism, such as conducting rural packaged tours, musical themed events, and advertising campaigns", according to interviewees. The interviewees listed several problems to account for tourism development during the meetings, the most common of which were a lack of infrastructure and service, poor community engagement, isolation and distance from urban centers, limited accessible areas and transportation options, and a lack of public-private tourism partnerships. The case study interviewees identified that the main problem with tourism promotion is that "Bibracte does not have its own image of a tourist destination such as other national sites". According to the evidence gathered during talks and meetings, this may be attributed to two primary factors: a substantial percentage of the surrounding population having emigrated from big cities in search of pasture, low demographic density, and a rural atmosphere; and the surrounding population's opposition to tourism development. The general consensus among the staff is that any tourism-promoting intervention would restrict the performance of tourist efforts and, as a consequence, the living patterns of the nearby residents would weaken the tourism process. Based on the information obtained, the most significant problem facing tourism development is the lack of and inability to define and build an appropriate tourism formula that is tailored to the local environment and potential tourists. Integrated management of the site is therefore concerned with setting the balance between management, interpretation, sustainable tourism, and the interests of both visitors and the local community.

According to the results of the preceding research, many difficulties and challenges may be traced back to three circles and levels (Figure 4): the site inner circle, the local context inner circle, and the countrywide inner circle. The attention of the present administration, which is focused on the partial physical and cultural significance of the site, is one of the challenges arising from the site's inner circle. The second circle's challenges include low local community engagement and site-specific tourism desires that go unspoken by the local community, while the third circle's challenges include a long list of stringent guidelines and criteria imposed to obtain various national labels. Thus, this recognition comes with a great deal of responsibility for its stewardship. With specific reference to the analysis and the identified problems, it would appear that the most crucial challenge facing the management of the archaeological site is the issue of balance-the balance between the requirements and the needs related to the different circles.

However, the challenge of ideal heritage management and tourism paradigms and concepts such as sustainability and integrity are not limited to the site of Bibracte.The findings of this study appear to be consistent with other studies on sites around the world; this reflects the observation in [30] that sites lack clarityon how to deal with tourism planning. This also aligns with the observations of [63] regarding how management practices and sustainability of heritage management are subject to social and political issues. Additionally, [79] notes that stakeholder cooperation is one of the crucial problems in heritage management, and is impacted by the dynamic relationship between the sites and their environment $[65,80]$. 


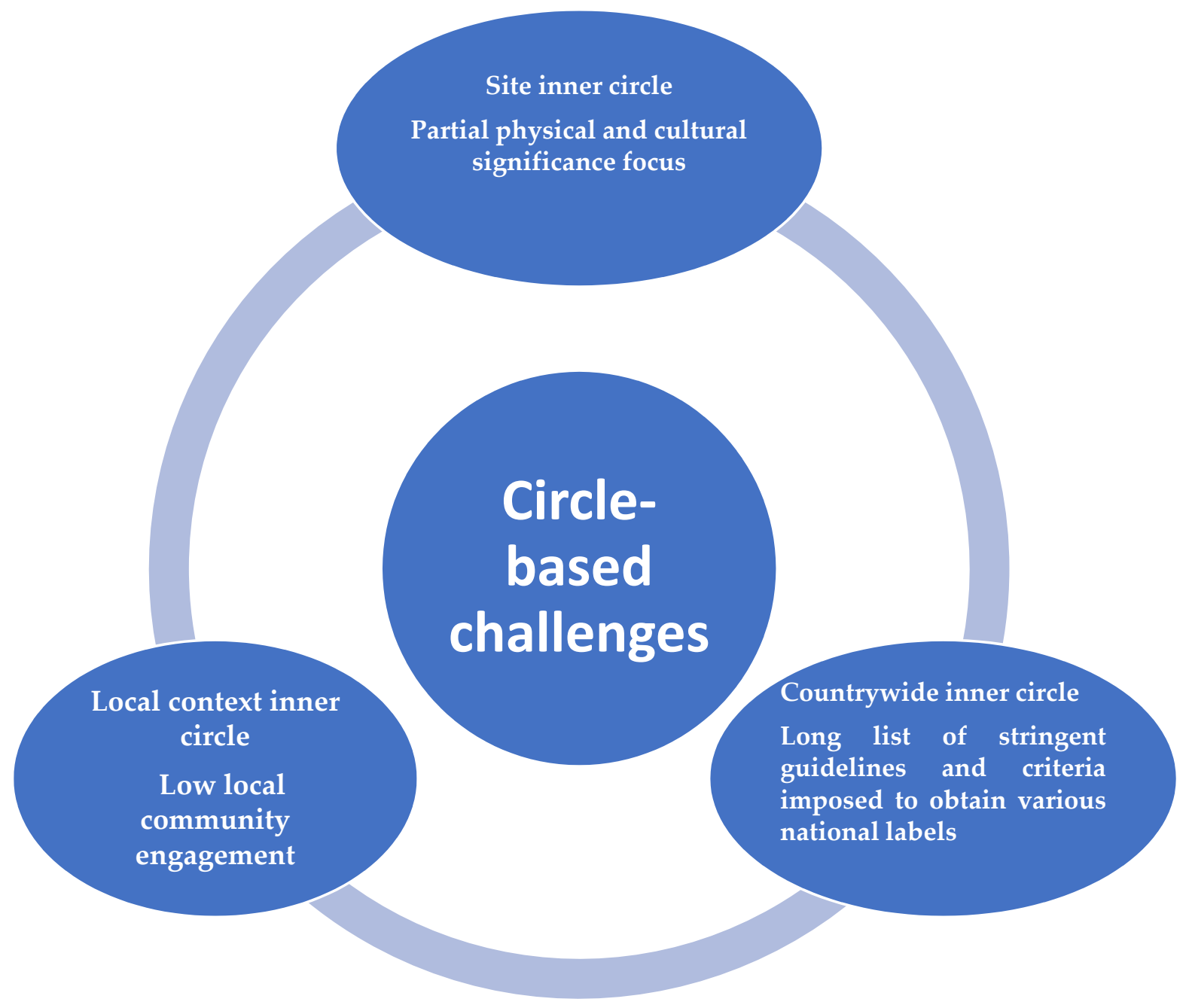

Figure 4. Management problems faced by Bibracte using three circles and levels.

\section{Conclusions}

The heritage management of Bibracte has been the subject of substantial professional and intellectual effort, and the work done there is considered to be extremely advanced However, this study reveals significant heritage management interpretation and tourist development issues. Substantial efforts have primarily been concentrated on surveys, excavations, and site management, without taking into account the interaction and symbiotic concerns connected to the site and its local context. Furthermore, previous valuable efforts have been devoted to the management of the archaeological sites, museum/interpretation center, research center development, and tourism development, with little consideration given to the analysis of the challenges related to the general landscape of the sites' context. In other words, very little weight has been given to the potential challenges that could emerge from these sites [2].

This study found that the most important challenge facing the site's current management is the low capture of the full breadth of the elements (cultural and natural; site-based and rural-environment-based) thatare necessary to manage, interpret and develop tourism at the site. The most pressing challenge, however, is striking a balance between site's management, interpretation, and tourism on the one hand, and preserving the present living pattern in the rural region surrounding Bibracte on the other. This study's final finding is that the site's management offers the potential for a variety of distinct and wide-ranging options. As a result, sites in rural areas must reflect the viewpoints of the larger setting. 
Consequently, it is recommended that various studies be conducted to identify natural and cultural resources, map values, and evaluate other management-related activities, such as visitor management, site potential, and research of the site's public.

Funding: This research was partially funded by Agence Universitaire de la Francophonie (AUF).

Institutional Review Board Statement: Not applicaple.

Informed Consent Statement: Not applicaple.

Data Availability Statement: Not applicaple.

Acknowledgments: The author would like to express his gratitude to the Agence Universitaire de la Francophonie (AUF) for their partial financial support, and to Bibracte EPCC for supporting the research visit. I would also like to express my appreciation toward site director and the entire team at Bibracte for providing me with a pleasant and productive stay at the archaeological site.

Conflicts of Interest: The author declares no conflict of interest.

\section{References}

1. Gravari-Barbas, M.; Jacquot, S. Villes Françaises du Patrimoine Mondiale et Tourisme, Protection, Gestion, Valorisation. 2010. Available online: https:// chaire-unesco-culture-tourisme.pantheonsorbonne.fr/sites/default/files/inline-files/VILLES_ PATRIMOINE_MONDIAL_IREST_CHAIRE_0.pdf (accessed on 1 February 2019).

2. Moore, T.; Guichard, V.; Alvarez Sanchs, J. The place of archaeology in integrated cultural landscape management. A case study comparing landscapes with Iron Age oppida in England, France and Spain. J. Eur. Landsc. 2020, 1, 9-28. [CrossRef]

3. Para, L.; Vourc'h, A. Heritage sites and sustainable tourism as leverage for local development: The grand site de France. P3T Public Policies Territ. 2012, 1,6.

4. Greffe, X. Etude Nationale des Retombées Economiques et Sociales du Patrimoine; Ministère de la Culture et de la Communication: Paris, France, 2009.

5. Marceau, G.; Metzger, T.; Azoury, N. Gestion territoriale et valorisation du patrimoine: Vers un développement régional durable. Gest. Organ. 2015, 7, 44-56.

6. Poirier, P. Gestion d'un Patrimoine Culturel en France: État des Lieux et Perspective, Nîmes. Mémoire de Fin D'étude. 2005. Available online: www.iquesta.com/.../Telecharger-Mémoiregestion-d-un-patrimoine-culturel-en-france-etat-des-lieux-etperspectives-155 (accessed on 15 February 2019).

7. Tully, G.; Piai, C.; Rodríguez-Hernández, J.; Delhommeau, E. Understanding Perceptions of Cultural Landscapes in Europe: A Comparative Analysis Using 'Oppida' Landscapes. Hist. Environ. Policy Pract. 2019, 10, 198-223. [CrossRef]

8. Guichard, V. Raconter la Construction des Territoires: Une Nouvelle Mission Pour les Musées D'archéologie. In Une Histoire des Civilisations. Les révolutions de L'archéologie Contemporaine; Demoule, J.-P., Garcia, D., Schna, A., Eds.; La Découverte/Dominique Carré: Paris, France, 2018; pp. 579-583.

9. Guichard, V. An Example of Integrated Management of a Heritage Site: Bibracte-Mont Beuvray (Burgundy, France). In Less More Architecture Design Landscape. Le Vie dei Mercanti. X Forum Internazionale di Studi; La Sucuola di Pitagora: Napoli, Italy, 2012.

10. Rahman, S. Heritage management challenges in historic town of Ludlow, England. World Appl. Sci. J. 2013, 24, 1589-1596.

11. Jean, J.S.; Joseph, M.; Louis, C.; Michel, J. Haitian Archaeological Heritage: Understanding Its Loss and Paths to Future Preservation. Heritage 2020, 3, 733-752. [CrossRef]

12. Yilmaz, Y.; Rehab, E.L. Cultural Heritage Management in Turkey and Egypt: A Comparative Study. Adv. Hosp. Tour. Res. 2018, 6, 68-91. [CrossRef]

13. -Fatorić, S.; Egberts, L. Realising the potential of cultural heritage to achieve climate change actions in the Netherlands. J. Environ. Manag. 2020, 274, 111107. [CrossRef]

14. Du Cros, H.; Yok-shiu, F.L. (Eds.) Cultural Heritage Management in China: Preserving the Cities of the Pearl River Delta; Routledge: London, UK, 2017.

15. Hodder, I. Archaeological Theory Today; Polity Press: Cambridge, UK, 2012.

16. Messenger, P.M.; Smith, G. Cultural Heritage Management. A Global Perspective; University Press of Florida: Gainesville, FL, USA, 2010.

17. Mangialardi, G.; Corallo, A.; Esposito, M.; Fortunato, L.; Monastero, A.; Schina, L. An integrated and networked approach for the cultural heritage lifecycle management. Encatc. J. Cult. Manag. Policy 2016, 1, 80-95.

18. Timothy, D. Making sense of heritage tourism: Research trends in a maturing field of study. Tour. Manag. Perspect. 2018, 25, 177-180. [CrossRef]

19. Willems, A.; Thomas, S.; Castillo Mena, A.; Čeginskas, V.; Immonen, V.; Kalakoski, I.; Mazel, A.D. Teaching Archaeological Heritage Management. Towards a Change in Paradigms. Conserv. Manag. Archaeol. Sites 2018, 20, 297-318. [CrossRef]

20. Vecco, M. A definition of cultural heritage: From the tangible to the intangible. J. Cult. Herit. 2010, 11, 321. [CrossRef]

21. Borowiecki, K.J.; Forbes, N.; Fresa, A. Cultural Heritage in a Changing World; Springer: Berlin/Heidelberg, Germany, 2016. 
22. Ross, D.; Saxena, G.; Correia, F.; Deutz, P. Archaeological tourism: A creative approach. Ann. Tour. Res. 2017, 1, 37-47. [CrossRef]

23. Bandarin, F.; Van Oers, R. The Historic Urban Landscape Managing Heritage in Urban Century, 1st ed.; John Wiley \& Sons: Hoboken, NJ, USA, 2012.

24. De la Torre, M. Values and heritage conservation. Herit. Soc. 2013, 6, 155-166. [CrossRef]

25. Doumas, C.G. Managing the archaeological heritage: The case of Akrotiri, Thera (Santorini). Conserv. Manag. Archaeol. Sites 2013, 15, 109-120. [CrossRef]

26. Magliacani, M. Managing Cultural Heritage: Ecomuseums, Community Governance, Social Accountability; Springer: Berlin/Heidelberg, Germany, 2014.

27. Manning, R. Visitor experience and resource protection: A framework for managing the carrying capacity of National Parks. J. Park Recreat. Adm. 2001, 19, 93-108.

28. Enseñat-Soberanis, F.; Frausto-Martínez, O.; Gándara-Vázquez, M. A visitor flow management process for touristified archaeological sites. J. Herit. Tour. 2019, 14, 340-357. [CrossRef]

29. Ahmad, Y. The Scope and Definitions of Heritage. Int. J. Herit. Stud. 2006, 12, 292-300. [CrossRef]

30. Makuvaza, S. (Ed.) Aspects of Management Planning for Cultural World Heritage Sites: Principles, Approaches and Practices; Springer: Berlin/Heidelberg, Germany, 2017.

31. Sullivan, S. A Planning Model for the Management of Archaeological Sites. In The Conservation of Archaeological Sites in the Mediterranean Region; de la Torre, M., Ed.; The Getty Conservation Institute: Los Angeles, CA, USA, 1997 ; pp. 15-26.

32. Feilden, B.M.; Jokilehto, J. Management Guidelines for World Cultural Heritage Sites; ICCROM: Rome, Italy, 1998.

33. Stovel, H. Risk Preparedness: A Management Manual for World Cultural Heritage; ICCROM: Rome, Italy, 1998.

34. The Burra Charter (The Australia ICOMOS Charter for Places of Cultural Significance). 1999. Available online: http:// openarchive.icomos.org/id/eprint/2145/ (accessed on 22 August 2021).

35. Demas, M. Planning for Conservation and Management of Archaeological Sites. In Management Planning for Archaeological Sites; Teutonico, J.M., Palumbo, G., Eds.; The Getty Conservation Institute: Los Angeles, CA, USA, 2002; pp. $27-54$.

36. Ringbeck, B. Management Plans for World Heritage Sites. A Practical Guide; German Commission for UNESCO: Bonn, Germany, 2008.

37. Cleere, H. Management plans for archaeological sites: A world heritage template. Conserv. Manag. Archaeol. Sites 2010, 12, 4-12. [CrossRef]

38. Mason, R. Assessing Values in Conservation Planning: Methodological Issues and Choices. In Assessing the Values of Cultural Heritage: Research Report; de la Torre, M., Ed.; The Getty Conservation Institute: Los Angeles, CA, USA, 2003; pp. 5-30.

39. Ababneh, A. Heritage Management and Interpretation: Challenges to Heritage Site-Based Values, Reflections from the Heritage Site of Umm Qais, Jordan. Archaeologies 2016, 12, 38-72. [CrossRef]

40. Avrami, E.; Macdonald, S.; Mason, R.; Myers, D. (Eds.) Values in Heritage Management: Emerging Approaches and Research Directions; Getty Conservation Institute: Los Angeles, CA, USA, 2019.

41. Den, W. Community empowerment and heritage conservation: The experience of Beitou District in Taipei City, Taiwan. Hist. Environ. Policy Pract. 2014, 5, 258-274. [CrossRef]

42. Polyzoudi, A. Archaeological Heritage as Palimpsest. The Multiple Layers of Contents of a Byzantine Tower and the Challenges of Sustainable Management Planning. Hist. Environ. Policy Pract. 2013, 4, 129-138. [CrossRef]

43. Poulios, I. Discussing strategy in heritage conservation: Living heritage approach as an example of strategic innovation. J. Cult. Herit. Manag. Sustain. Dev. 2014, 4, 16-34. [CrossRef]

44. Taylor, K.; Lennon, J. (Eds.) Managing Cultural Landscapes; Routledge: London, UK, 2012.

45. Imon, S.S.; Ong, C.E. Cultural Tourism Site Management: A Training Manual for Trainers in the Greater Mekong Sub-Region; United Nations Economic and Social Commission for Asia and the Pacific (UNESCAP) and Institute For Tourism Studies (IFT): Macao, China, 2007.

46. Ababneh, A. Situational Analysis of Archaeological Site's Interpretation Based on Examples from Jordan. Archaeologies 2017, 13, 278-305. [CrossRef]

47. Kausar, D.R.; Nishikawa, Y. Heritage tourism in rural areas: Challenges for improving socio-economic impacts. Asia Pac. J. Tour. Res. 2010, 15, 195-213. [CrossRef]

48. Kim, S.; Lee, H. Visitor attention and communication in information based exhibitions. Int. J. Des. 2016, 10, 15-30.

49. Ababneh, A. The Site of Pella in Jordan: A Case Study for Developing Interpretive Strategies in an Archaeological Heritage Attraction. Near East. Archaeol. 2018, 81, 100-107. [CrossRef]

50. Hodges, S. Building Peace: The Role of Heritage Interpretation. Public History. 2019. Available online: https://epress.lib.uts.edu. au/journals/index.php/phrj/article/view/ 6853 (accessed on 17 July 2021).

51. Beck, L.; Cable, T.T.; Knudson, D.M. Interpreting Cultural and Natural Heritage: For a Better World; Sagamore Publishing: Champaign, IL, USA, 2018.

52. Wyatt, B.; Leask, A.; Barron, P. Designing dark tourism experiences: An exploration of edutainment interpretation at lighter dark visitor attractions. J. Herit. Tour. 2010, 1-17.

53. Hvenegaard, G.T. Visitors' perceived impacts of interpretation on knowledge, attitudes, and behavioral intentions at Miquelon Lake Provincial Park, Alberta, Canada. Tour. Hosp. Res. 2017, 17, 79-90. [CrossRef] 
54. Brochu, L.; Merriman, T. Redefining interpretation as a core belief for certification of professionals. J. Intepretation Res. 2002, 7, 11-16. [CrossRef]

55. Li, H.; Qian, Z. Archaeological heritage tourism in China: The case of the Daming Palace from the tourists' perspective. J. Herit. Tour. 2017, 12, 380-393. [CrossRef]

56. World Tourism Organization. Tourism and Culture Synergies; UNWTO: Madrid, Spain, 2018.

57. Zhang, C.; Fyall, A.; Zheng, Y. Heritage and tourism conflict within world heritage sites in China: A longitudinal study. Curr. Issues Tour. 2015, 18, 110-136. [CrossRef]

58. Alazaizeh, M.M.; Jamaliah, M.M.; Mgonja, J.T.; Ababneh, A. Tour guide performance and sustainable visitor behavior at cultural heritage sites. J. Sustain. Tour. 2019, 27, 1708-1724. [CrossRef]

59. Cho, M.; Shin, S. Conservation or economization? Industrial heritage conservation in Incheon, Korea. Habitat Int. 2014, 41, 69-76. [CrossRef]

60. Timothy, D. Introduction. In Managing Heritage and Cultural Tourism Resources; Timothy, D.J., Ed.; Routledge: Abingdon, UK, 2016; pp. 11-14.

61. Zan, L. Cultural Heritage in China: Between Policies, Development, Professional Discourse, and the Issue of Managing. Public Archaeol. 2014, 13, 99-112. [CrossRef]

62. Leask, A. Visitor attraction management: A critical review of research. Tour. Manag. 2016, 57, 334-361. [CrossRef]

63. Álvarez, M.P. Conservation Realities and Challenges at Archaeological and Historical Sites in Colombia: Seeking Success by Considering the Context. In Objects Specialty Group Postprints, Volume Twenty-One; Davis, S., Ed.; The American Institute for Conservation of Historic \& Artistic Works: Washington, DC, USA, 2014; pp. 323-344.

64. Kausar, D.R.K.; Gunawan, M.P. Managing heritage tourism in Toraja: Strengthening local values and improving tourists' experiences. J. Herit. Tour. 2017, 13, 550-561. [CrossRef]

65. Rotherham, I.D.; Ardron, P.A. The archaeology of woodland landscapes: Issues for managers based on the case-study of Sheffield, England and four thousand years of human impact. Arboric. J. 2006, 29, 229-243. [CrossRef]

66. McKercher, B.; Du Cros, H. Cultural Tourism: The Partnership between Tourism and Cultural Heritage Management; Routledge: London, UK, 2002.

67. Bhati, A.; Pearce, P. Vandalism and tourism settings: An integrative review. Tour. Manag. 2016, 57, 91-105. [CrossRef]

68. Högberg, A.; Holtorf, C.; May, S.; Wollentz, G. No future in archaeological heritage management? World Archaeol. 2017, 49, 639-647. [CrossRef]

69. Baxter, I. From heritage to historic environment: Professionalizing the experience of the past for visitors. J. Hosp. Tour. 2004, 2 , 1-14.

70. Pattin, V. Tourisme et Patrimoine en France et en Europe; La Documentation Française: Paris, France, 1997.

71. Bramwell, B.; Meyer, D. Power and tourism policy relations in transition. Ann. Tour. Res. 2007, 34, 766-788. [CrossRef]

72. Romero, A.M.; Maillier, A. Bibracte: Archéologie D'une Ville Gauloise; Bibracte, Centre Archéologique Européen: Glux-en-Glenne, France, 2006.

73. Guichard, V.; Chazelle, C. Mettre en Valeur L'invisible: Réflexions sur le Site Archéologique de Bibracte. In De la Restitution en Archéologie, Actes du Colloque de Béziers (Octobre 2005); Bellet, M.-E., Chazelle, C.L., Eds.; Centre des Monuments Nationaux: Paris, France, 2007; pp. 179-186. Available online: http:/ / editions.monuments-nationaux.fr (accessed on 4 April 2019).

74. Chazelle, C. Bibracte Mont-Beuvray. Gestion du Grand Site et de ses Territoires. Elements de Diagnostic Paysager; ClermontFerrand: Atelier Claude Chazelle. 2017. Available online: http://www.bibracte.fr/media/bibracte/163210-2017_chazelle_ diagnostic_paysager.pdf (accessed on 1 June 2021).

75. Bibracte. Available online: www.bibracte.fr (accessed on 1 June 2021).

76. Lemarchand, F.; Maillier, A. Bibracte: Une Ville Entre Deux Mondes; CAE Européen Mont-Beuvray: Glux-en-Glenne, France, 2017.

77. Tabardy, D.; Maillier, A. Bibracte-Mont Beuvray: Grand Site de France; Les Nouvelles Éditions de l'Université; Petit futé, Beaux Livres/Grand Site de France: Paris, France, 2015.

78. Chazelle, C.; Guichard, V. Mettre en Valeur L'invisible: Une Réflexion à Propos du Site Archéologique de Bibracte. In Gestion et Présentation des Oppida: Un Panorama Européen, Actes de la Table Ronde de Beroun (CZ), 26 Septembre 2007; Benková, I.I., Guichard, V., Eds.; Institut Archéologique de Bohême Centrale: Beroun, Czech Republic, 2008; pp. 179-186.

79. Ayalew, K. Heritage Management on the Ground Heritage Conservation Versus Local Community in Lalibela (Ethiopia). Master's Thesis, Universidade de Évora, Paris, France, 2016.

80. Hughes, M.; Carlsen, J. The business of cultural heritage tourism: Critical success factors. J. Herit. Tour. 2010, 5, 17-32. [CrossRef] 